\title{
FULMINANT IDIOPATHIC INTRACRANIAL HYPERTENSION IN A PEDIATRIC PATIENT FOLLOWING A MINOR HEAD TRAUMA
}

In the issue number 3, vol 67 of the Arquivos de NeuroPsiquiatria, Lin et al.' published a very intriguing case of fulminant idiopathic intracranial hypertension (IIH) in an 11 years-old boy after minor head trauma. After extensive work-up no diagnosis was found and the authors discussed properly the most important causative agents of secondary pseudotumor cerebri.

We take the opportunity to include an additional differential diagnosis to this interesting situation, namely delayed ce- 
rebral edema (DCE) associated with CACNA1A calcium channel subunit gene mutations, a very rare condition published in 2001, by Kors et al. ${ }^{2}$. These authors reported a series of three subjects with DCE after minor head trauma. DCE is a condition related to trivial head trauma, complicated by severe, cerebral edema and even coma, occurring after a lucid interval ${ }^{2-4}$. Kors et al. ${ }^{2}$ investigated the role of the CACNA1A gene and found a novel S218L mutation in the CACNA1A calcium channel subunit gene. Mutations in the CACNA1A gene are associated with several episodic neurological diseases, including migraine, familial hemiplegic migraine, episodic ataxia type 2 , and spinocerebellar ataxia type $6^{2}$.

Although the authors did not find a family history that indicated any form of Mendelian inheritance of neurological disorders in this case report, this may not always be evident as clinical manifestation varies widely even among members of the same family.

\section{REFERENCES}

1. Lin J, Fernandes JKS, Faria EC, Pinho RS, Masruha, Vilanova
LCP. Fulminant idiopathic intracranial hypertension in a pediatric patient following a minor head trauma. Arq Neuropsiquiatr 2009;67:519-522.

2. Kors EE, Terwindt GM, Vermeulen FLMG, et al. Delayed cerebral edema and fatal coma after minor head trauma: role of the CACNA1A calcium channel subunit gene and relationship with familial hemiplegic migraine. Ann Neurol 2001;49:753-760.

3. McCrory PR, Berkovi SF. Second impact syndrome. Neurology 1998;50:677-683.

4. Snoek JW, minderhout JM, Wilmink JT. Delayed deterioration following mild head injury in children. Brain 1984;107:15-36.

Hélio A.G. Teive, MD, PhD

Renato P. Munhoz, MD

Movement Disorders Unit

Neurology Service, Hospital de Clínicas,

Federal University f Paraná

Curitiba, PR (E-mail: hagteive@mps.com.br) 